\title{
Pembiayaan Kredit Usaha Rakyat Di Bank BRI Syariah Kantor Cabang Sidoarjo
}

\author{
Rahmi Eka Ratnani \\ UIN Sunan Ampel Surabaya \\ Email Penulis: rahmika2@gmail.com \\ Firman Pramudya \\ UIN Sunan Ampel Surabaya \\ Email Penulis: firmanpramudya02@gmail.com \\ Lingga Parama Liofa \\ UIN Sunan Ampel Surabaya \\ Email Penulis: paralingga@gmai.com \\ M. Irfan Izzuddin R \\ UIN Sunan Ampel Surabaya \\ Email Penulis: izzuddin.irfan2181@gmail.com \\ Nur Lailatul Musyafaah \\ UIN Sunan Ampel Surabaya \\ Email Penulis: nurlailatul@uinsby.ac.id
}

\begin{abstract}
People's Business Credit is one way to help MSME traders get business capital. KUR financing can be done in banks, including Islamic Banks. Bank BRI Syariah also offers KUR financing. This article examines the funding of Medium Enterprise Credit at Bank BRI Syariah Sidoarjo. The research is field and qualitative, and the data was collected through observation, interviews, and documentation. The collected data was analyzed with the concept of murābahah bil wakalah. This research concluded that customers could apply for KUR approval to BRI Syariah with the conditions set by the bank. Akad is done with murābahah bil wakalah. Then the customer gets money from the bank; then, the bank represents the customer to spend the goods with the money. The bank gives 14 days to provide a statement to the bank and submit a receipt for further processing. The concept has been in accordance with the elements and conditions of murābahah bil wakalah. As for customers who violate the specified time limit, the bank conducts education and reprimands customers. That is part of the cooperation process that all parties must trust each other.
\end{abstract}

Kata kunci: UMKM, KUR, Sharia Bank

\begin{abstract}
Abstrak
Kredit Usaha Rakyat merupakan salah datu cara membantu pedagang saha Mikro, Kecil dan Menegah (UMKM) mendapatkan modal usaha. Pembiayaan KUR bisa dilakukan di bank, termasuk Bank Syariah. Bank BRI Syariah juga menawarkan pembiayaan KUR. Artikel ini mengkaji secara mendalam tentang pembiayaan Kredit Usaha Menengah di Bank BRI Syariah Sidoarjo. Penelitian ini adalah penelitian lapangan dan kualitatif. Pengumpulan data dilakukan melalui observasi, wawancara dan dokumentasi. Data yang terkumpul dianalisis dengan konsep murābaḥah bil wakalah. Penelitian ini menyimpulkan bahwa nasabah bisa mengajukan pembiyaan KUR ke BRI Syariah dengan syarat yang telah ditetapkan bank. Akad dilakukan dengan murābahah bil wakalah. Maka nasabah mendapat uang dari bank, lalu bank mewakilkan nasabah untuk membelanjakan barang dengan uang tersebut. Bank
\end{abstract}


memberi waktu 14 hari, agar nasabah memberikan laporan kepada bank dan menyerahkan struk belanja untuk diproses lebih lanjut. Konsep tersebut telah sesuai dengan unsur dan syarat murābahah bil wakalah. Adapun bagi nasabah yang melanggar dari batas waktu yang ditentukan, maka bank melakukan edukasi dan peneguran kepada nasabah. Hal tersebut merupakan bagian dari proses kerjasama, bahwa semua pihak harus saling amanah.

Kata kunci: UMKM, KUR, Bank Syariah.

\section{A. Pendahuluan}

Perkembangan perekonomian Islam semakin pesat seiring dengan berkembangnya zaman. Hal itu juga berdampak kepada sistem perbankan Islam yang semakin meluas baik dalam internasional dan nasional. ${ }^{1}$ Bank syariah merupakan salah satu produk perbankan yang memiliki landasan sistem perekonomian Islam atau lebih dikenal ekonomi syariah. Bank syariah di Indonesia pada awalnya dikembangkan sejak tahun 1994 dengan didirikannya Bank Muamalat. ${ }^{2}$

Indonesia merupakan negara dengan mayoritas muslim. Meski demikian, dalam awal-awal munculnya, bank syariah masih belum memiliki banyak peminat seperti masa sekarang. Dalam kurun waktu yang lumayan, kegiatan perbankan masih banyak menggunakan konvensional. Adapun faktor yang dapat mempengaruhi diantaranya kurangnya edukasi yang diterima masyarakat mengenai bank syariah. Namun, seiring berjalannya waktu serta mulai banyak bank syariah yang telah hadir di Indonesia membuat masyarakat perlahan namun pasti berpindah menggunakan bank syariah. ${ }^{3}$

Salah satu keunggulan bank syariah yang banyak dipahami oleh masyarakat luas terletak pada sistem bagi hasil. Sehingga banyak masyarakat menyebut bank syariah dengan bank bagi hasil atau nisbah. Akan tetapi pada kenyataannya pembiayaan di perbankan syariah tidak banyak didominasi dengan pembiayaan bagi hasil atau dikenal dengan akad mudharabah, melainkan didominasi dengan pembiayaan yang diketahui margin keuntungannya atau kita mengenalnya dengan akad murābaḥah. ${ }^{4}$

Pembiayaan dengan akad murābaḥah selalu menjadi primadona dibandingkan

\footnotetext{
${ }^{1}$ Fitrianur Syarif, "Perkembangan Hukum Ekonomi Syariah Di Indonesia," Pleno Jure 9, no. 2 (2019): 1, https://doi.org/10.37541/plenojure.v8i2.38.

2 Muh Shadiqul Fajri AF, "Penerapan Shariah Compliance Dalam Alur Pembiayaan Murabahah Pada Bank Muamalat Indonesia Cabang Makassar," Jurnal Iqtisaduna 6, no. 1 (2020): 27, https://doi.org/10.24252/iqtisaduna.v6i1.14061.

${ }^{3}$ Nur Haida et al., "Pengaruh Pemahaman Masyarakat Tentang Riba Terhadap Minat Bertransaksi Di Bank Syariah," Ecobankers: Journal of Economy Banking 2, no. 2 (2021): 131.

4 Yenti Afrida, "Analisis Pembiayaan Murabahah Di Perbankan Syariah," Jebi Jurnal Ekonomi Dan Bisnis Islam) 1, no. 2 (2016): 155, http://journal.febi.uinib.ac.id/index.php/jebi/article/view/32.
} 
dengan produk perbankan lainnya. Hal ini dikarenakan dalam pelaksanaannya mudah dipahami oleh nasabah. Hal ini bisa dibuktikan dari jumlah rekening bank pembiayaan syariah (Number Of Occount of Shariah Rural Bank). ${ }^{5}$

Tabel 1. Jumlah Rekening Bank Pembiayaan Rakyat Syariah Jumlah Rekening Bank Pembiayaan Rakyat Syariah (number of occount of Shariah Rural Bank) 2020

\begin{tabular}{|l|r|r|r|l|}
\hline Jenis & \multicolumn{1}{|l|}{ Juli } & \multicolumn{1}{l|}{ Agustus } & Type \\
\hline $\begin{array}{l}\text { Dana Pihak } \\
\text { Ketiga }\end{array}$ & $\mathbf{1 , 6 8 3 , 0 8 3}$ & $\mathbf{1 , 7 0 3 , 4 6 3}$ & $\mathbf{1 , 7 0 8 . 5 2 6}$ & $\begin{array}{l}\text { Depositor } \\
\text { funds }\end{array}$ \\
\hline Giro iB & - & - & $-\begin{array}{l}\text { Demand } \\
\text { deposits }\end{array}$ \\
\hline Tabungan iB & $1,624,704$ & $1,645,000$ & $1,649,517$ & Saving deposits \\
\hline Deposito iB & 58,379 & 58,463 & 58,809 & Time deposits \\
\hline Pembiayaan & $\mathbf{3 5 9 , 4 6 4}$ & $\mathbf{3 6 0 , 1 8 1}$ & $\mathbf{3 6 0 , 8 3 0}$ & Financing \\
\hline $\begin{array}{l}\text { Akad } \\
\text { Mudharabah }\end{array}$ & 3,168 & 3,079 & 3,043 & Mudharaba \\
\hline $\begin{array}{l}\text { Akad } \\
\text { Musyarakah }\end{array}$ & 8,677 & 8,606 & 8.709 & Musharaka \\
\hline $\begin{array}{l}\text { Akad } \\
\text { Murābahah }\end{array}$ & 279,710 & 281,257 & 282,509 & Murabaha \\
\hline Akad Salam & - & - & - & Salam \\
\hline Akad Istishna & 241 & 241 & 242 & Istishna \\
\hline Akad Ijarah & 38,004 & 37,263 & 36,729 & Ijarah \\
\hline Akad Qardh & 687 & 681 & 679 & Qardh \\
\hline Multijasa & 28,977 & 29,054 & 28,919 & $\begin{array}{l}\text { Multi purpose } \\
\text { financing }\end{array}$ \\
\hline Total & $\mathbf{2 , 0 4 2 , 5 4 7}$ & $\mathbf{2 , 0 6 3 , 6 4 4}$ & $\mathbf{2 , 0 6 9 1 5 6}$ & \\
\hline
\end{tabular}

Berdasarkan data di atas, dapat dipahami bahwa dari jumlah rekening pembiayaan bank syariah antara mudharabah dan murābaḥah memiliki perbedaan yang signifikan. Hal ini membuktikan bahwasanya masyarakat atau nasabah lebih memilih akad murābaḥah dalam mendapatkan pembiayaan dari bank syariah. Gambaran ini memberikan indikasi bahwasanya akad murābaḥah lebih mendominasi di perbankan syariah. ${ }^{6}$ Hal ini salah satunya disebabkan oleh sistem penentuan margin yang transparan karena dalam akad murābaḥah harga pokok dan keuntungan disepakati

5 “Statistik Perbankan Syariah - Agustus 2020," Otoritas Jasa Keuangan, 2020, https://www.ojk.go.id/id/kanal/syariah/data-dan-statistik/statistik-perbankan-syariah/Pages/StatistikPerbankan-Syariah---Agustus-2020.aspx.

${ }^{6}$ Nurul Afiqah Mutmainnah and Hadi Daeng Mapuna, "Peranan Restrukturisasi Dalam Akad Murābahah (Studi Kasus Putusan Nomor: 0293/Pdt.G/2017/ PA . Gtlo)," Qaḍ̄unā 1, no. 2 (2020): 90. 
bersama di antara kedua belah pihak.

Akad murābaḥah pada penerapannya di lembaga keuangan syariah telah mengalami berbagai modifikasi, sesuai dengan kondisi nasabah. Namun, sangat disayangkan karena modifikasi tersebut tidak sesuai dengan praktik murābaḥah yang ada di fikih. Salah satu produk yang sangat diminati nasabah yakni pembiayaan Kredit Usaha Rakyat (KUR), dimana pembiayaan ini merupakan pembiayaan dengan bantuan subsidi dari pemerintah yang diperuntukkan khusus untuk saha Mikro, Kecil dan Menegah (UMKM). ${ }^{7}$

KUR atau yang dapat diartikan Kredit Usaha Rakyat merupakan salah satu produk pembiayaan mikro yang diperuntukkan bagi wirausaha atau pengusaha dengan syarat usaha yang dilakukan telah berjalan minimal 6 bulan. Plafon yang dapat diajukan nasabah yakni dengan angka maksimal Rp.50.000.000. Produk KUR yang ditawarkan oleh BRI Syariah merupakan salah satu komitmen dari BRI Syraiah untuk ikut andil dalam pemajuan UMKM menengah kebawah. Hal tersebut dikarenakan pada sektor usaha mampu memberikan maslahah kepada masyarakat berupa penyerapan tenaga kerja serta mampu mengangkat perekonomian masyarakat menengah ke bewah untuk keluar dari jurang kemiskinan. ${ }^{8}$

Dalam produk KUR yang ditawarkan BRI Syariah menggunakan akad murabahah bil wakalah. Pihak nasabah yang memerlukan bantuan dana tambahan untuk usahanya dapat mengajukan dengan memilih plafon yang disesuaikan dengan kebutuhan nasabah. Dari pihak BRI Syariah akan meninjau kelayakan diberikannya pinjaman dana serta meminta data diri untuk diakukan BI Checking untuk melacak track record nasabah. Kemudian dari pihak BRI Syariah akan meninjau untuk kedua kalinya namun hal ini dilakukan oleh pihak marketing dan juga mengajak dari pihak pimpinan BRI Syariah. Setelah dilakukan pengecekan kelayakan, dari pihak nasabah dapat datang Ke BRI Syariah untuk membawa syarat administratif dan dapat dilakukan pencairan dana. Demi melindungi keamanan dari pihak nasabah, maka dana yang dicairkan akan auto debet dalam tabungan BRI Syariah sang nasabah. Namun, pihak nasabah masih memiliki kewajiban selain mengangsur cicilannya yakni menyetorkan struk belanja dana yang telah digunakan.

\footnotetext{
7 Riawan Riawan and Wawan Kusnawan, "Pengaruh Modal Sendiri Dan Kredit Usaha Rakyat (KUR) Terhadap Pendapatan Usaha (Studi Pada UMKM Di Desa Platihan Kidul Kec. Siman)," Jurnal Akuntansi Dan Pajak 19, no. 1 (2018): 34, https://doi.org/10.29040/jap.v19i1.158.

8 Sauqi, Account Officier Mikro BRI Syariah KC Sidoarjo, wawancara 2 Oktober 2020
} 
Dalam kenyataannya, pihak nasabah terkadang lalai akan hal tersebut. Terkadang nasabah menyetorkan struk atau kwitansi belanja yang tidak sesuai dengan akad yang telah disepakati secara bersama sama. Pihak Bank BRI Syariah sudah berusaha untuk memberikan edukasi penyadaran kepada pihak nasabah terkait struk yang harus sesuai dengan akad yang telah disepakati secara bersama sama. Bagaimanapun juga, struk adalah salah satu bentuk kontrol bank terhadap dana yang disalurkan kepada nasabah dan juga merupakan salah satu syarat keabsahan dari akad. Berdasarkan hal tersebut maka penulis tertarik untuk mengkaji "Pembiayaan Kredit Usaha Rakyat di Bank

\section{BRI Syariah Sidoarjo".}

\section{B. Konsep Murābahah Bil Wakalah}

Murābaḥah dalam konsep fiqh merupakan salah satu akad dari jual-beli ${ }^{9}$ yang memiliki sifat amanah. Akad murābaḥah dapat terlaksana dalam jual beli bila kedua belah pihak telah mengetahui harga pokok kemudian ditambah margin keuntungan yang diperoleh oleh pihak penjual. Secara etimologis, murābaḥah berasal berasal dari kata al-ribh (الرِّبْح) yang memiliki arti kelebihan atau pertambahan dalam jual-beli. Alribh dengan kata lain memiliki arti sebagai keuntungan, laba, faedah karena dalam jual beli Murābaḥah harus menjelaskan berapa margin keuntungannya. ${ }^{10}$ Sedangkan, secara istilah terdapat pendapat dari beberapa jumhur ulama.

Akad murābahah menurut Ulama Hanafiyah yaitu: "Mengalihkan kepemilikan sesuatu yang dimiliki melalui akad pertama dengan harga pertama disertai tambahan sebagai keuntungan". Sedangkan ulama Malikiyah mengemukakan definisimMurābaḥah yaitu: "Jual beli barang dagangan sebesar harga pembelian disertai dengan tambahan sebagai keuntungan yang sama diketahui kedua pihak yang berakad". Selain itu, ulama Syâfi'iyyah mendefinisikan murābaḥah dengan: "Jual beli dengan seumpama harga (awal), atau yang senilai dengannya, disertai dengan keuntungan yang didasarkan pada tiap bagiannya".11

Dalam pandangan Imam Syafi'i, jika seseorang menunjukkan sesuatu barang ke orang lain lalu berkata: "Belikan aku barang seperti ini maka aku akan memberimu keuntungan". Kemudian, orang tersebut membelikan barang yang diminta, maka jual

\footnotetext{
${ }^{9}$ Berbicara tentang Murabahah maka tidak akan dapat dilepaskan dengan sistem jual beli yang dalam fiqh biasa disebuat al-bai'. Yang secara etimologis kata al-bai' dapat diartikan dengan (المبا دلة) yang berarti tukar menukar.

${ }^{10}$ Wiroso, Jual Beli Murabahah (Yogyakarta: UII Press, 2005), 14.

11 "Konsep Murabahah Dalam Wacana Fikih," in Ensikolpedi Fikih Online, 2010, http://fikihonline.blogspot.com/search?q=murabahah.
} 
beli ini dianggap sah. Imam Syafi'i menamai transaksi jual beli ini dengan istilah alMurābaḥah li al-amir bi asy-syira' (Murābaḥah yang dilakukan untuk pembelian secara pemesaan). ${ }^{12}$ Dalam hal ini, calon pembeli dapat memesan barang yang diinginkan kepada seseorang (sebut saja pembeli) untuk membelikan suatu barang kepada penjual. Saat terjadinya permintaan, sebelumnya dilakukan kesepakatan mengenai harga pokok yang mampu ditanggung oleh calon pembeli. Setelah barang yang sudah diinginkan telah sesuai dengan permintaan calon pembeli, maka kedua belah pihak melakukan kesepakatan terhadap margin keuntungan yang didapat seseorang tersebut. Jual-beli tersebut baru dianggap sah jika calon pembeli sudah menerima barang pesanannya dan seseorang (pembeli) mendapatkan margin keuntungan. ${ }^{13}$

Di dalam al-Qur'an maupun Hadis tidak pernah dijelaskan secara langsung mengenai murābaḥah, akan tetapi membicarakan tentang jual-beli, laba, dan perdagangan. Oleh sebab itu, sebagai landasan syariah murābaḥah digunakan prinsip jual-beli dengan sistem pembayaran yang ditangguhkan. Landasan syariah di dalam AlQuran terdapat pada Q.S An-Nisa' [4] : 29; Q.S Al-Baqarah [2] : 275.14

Fatwa DSN MUI memberikan definisi mengenai murābahah yaitu menjual suatu barang dengan menegaskan harga belinya kepada pembeli dan pembeli membayarnya dengan harga lebih sebagai laba. ${ }^{15}$ Sedangkan dalam PSAK 59, Murābaḥah adalah akad jual beli barang dengan menyatakan harga perolehan perolehan dan margin keuntungan yang disepakati oleh penjual dan pembeli. Oleh sebab itu, Murābahah adalah kontrak atau akad yang berdasarkan kepercayaan.

Dari beberapa rumusan definisi murābaḥah oleh jumhur ulama serta Fatwa DSN MUI dapat disimpulkan bahwa akad murābaḥah adalah akad jual beli yang dilakukan dengan diketahui harga pokok ditambah margin keuntungan yang diperoleh oleh penjual. Jual-beli murābaḥah hanyalah kontrak penjualan yang menetapkan harga berdasarkan biaya penjual ditambah markup persentase yang ditentukan. Dalam hal ini yang menjadi dasar dari akad Murābaḥah adalah disepakatinya margin keuntungan antara kedua belah pihak. Kejujuran serta keterbukaan dari kedua belah menjadi syarat utama terjadinya akad murābahah. Sehingga yang menjadi karakteristik utama dari konsep murābaḥah adalah penjual harus memberi tahu calon pembeli mengenai harga

\footnotetext{
12 Muhammad Syafii Antonio, Bank Syariah: Dari Teori Ke Praktik (Jakarta: Gemma Insani, 2001), 102.

${ }^{13}$ Akhmad Mujahidin, Hukum Perbankan Syariah (Depok: PT Raja Grafindo Persada, 2017), 54.

${ }^{14}$ Ibid., 54-55.

15 Dewan Syariah Nasional MUI, "Fatwa DSN MUI No. 04/DSN-MUI/IV/2000 Tentang Murabahah" (Jakarta, 2000).
} 
pembelian barang serta menyatakan jumlah keuntungan yang ditambahkan pada biaya tersebut.

Kontrak murābaḥah dalam sistem keuangan Islam, sudah sangat jelas bahwa di dalam Islam jalur kredit menggunakan bunga dilarang. Akan tetapi di dalam akad murābaḥah dapat menggantikan jalur kredit, di mana akad murābaḥah melibatkan penjualan barang dengan mark up keuntungan yang telah diketahui dengan harga pokok. Misalnya, jika seorang pengusaha membutuhkan Rp.50.000.000.- untuk membeli bahan baku, beliau dapat mengatur bank syariah atau investor lain untuk membeli barang atas namanya lalu menambahkan margin keuntungan dan menjual kembali barang tersebut, katakanlah Rp.55.000.000.- dengan pembayaran ditunda selama lima bulan. Margin keuntungan tersebut sepenuhnya dapat diterima menurut hukum Islam. Itu dapat mencakup apapun yang penjual pilih untuk disertakan, tanpa pertanyaan yang diajukan atau pembenaran yang diperlukan. Dengan demikian, selain biaya aktual yang timbul dalam proses kesepakatan murābaḥah, penjual dapat mengisi biaya untuk halhal seperti resiko bahwa pembeli tidak membayar barang, risiko dalam pembayaran mata uang asing yang membuat penjual kurang beruntung, dan yang paling penting biaya peluang penjual dalam mengikat uangnya sampai pembeli benar-benar membayarnya. Biaya terakhir ini -untuk ikatan modal investor- mewakili perbedaan yang sangat halus dari pengisian bunga langsung. ${ }^{16}$

Meskipun hukum Islam melarang pinjaman dengan bunga, hutang dan instrumen kredit tetap memainkan peranan penting dalam struktur modal bisnis Muslim. Ingatlah bahwa kontrak murābaḥah (penjualan kredit) adalah bentuk yang sangat populer dari Islam, yaitu kontrak utang jangka pendek dan menengah. Ini melibatkan penjualan langsung, tetapi dengan persyaratan kredit yang menentukan pembayaran pada titik akhir atau pembayaran cicilan pada titik-titik tertentu. Setiap angsuran dapat dilihat sebagai pengembalian modal dan kompensasi untuk nilai waktu uang. Untuk menunjukkan, jika x adalah biaya administrasi mendapatkan kredit, sebagai persentase dari nilai nominal pinjaman, dan hasil bruto pinjaman adalah $\mathrm{P}$, hasil bersih untuk pembeli adalah $\mathrm{P}(1-\mathrm{x})$. Jika hanya ada dua setengah tahunan angsuran dari nilai $I$ untuk murābaḥah dengan jatuh tempo satu tahun dan y tingkat pengembalian (IRR) secara tahunan, maka:

\footnotetext{
${ }^{16}$ Frank E. Vogel and Samuel L. Hayes, Islamic Law and Finance (Religion, Risk, and Return) (Netherlands: Kluwer Law International, 1998), 182.
} 


$$
P(1-x)=[I:(1+y)]+[1:(1+y)]
$$

Pemecahan pada $y$ akan memberikan perkiraan biaya modal kepada pembeli murābahah. ${ }^{17}$

Wakalah atau wikalah berarti penyerahan, pendelegasian, atau pemberian mandat. Dalam bahasa arab, hal ini dapat dipahami sebagai at-tafwidh. Contoh kalimat “aku serahkan urusanku kepada Allah". Wakalah bermakna penyerahan atau pemberian mandat (pelimpahan wewenang) oleh seseorang pada yang lain dalam hal diwakilkan. Para ulama sepakat kebolehan wakalah ini, bahkan cenderung mensunnahkan dengan alasan ta'awannual albirri wa al-taqwa. Dalam perbankan, nasabah mewakilkan pada pihak bank atas urusan keuangan yang dipunyai, dalam hal ini bank sebagai wakil.18 Adapun landasan syariah mengenai wakalah terdapat pada Al-Quran Q.S Al-Kahfi [18] : 19 dan Q.S Yusuf [12]: 55.19

Murābahah bil wakalah merupakan praktik jual beli dengan sistem wakalah. Jual beli dengan sistem ini dimana pihak penjual mewakilkan pembeliannya kepada pihak lain untuk melakukan akad jual beli. ${ }^{20}$ Dengan demikian akad pertama dalam praktik murābaḥah bil wakalah ialah akad wakalah. Setelah akad wakalah berakhir, maka para pihak menjalankan akad murābaḥah.

Sesuai dengan Fatwa DSN MUI yang memberikan ketentuan pada pasal 1 ayat 9: "jika bank hendak mewakilkan kepada nasabah untuk membeli barang dari pihak ketiga, akad jual beli Murābahah harus dilakukan setelah barang, secara prinsip, menjadi milik bank."21 Berdasarkan ketentuan tersebut, akad murābaḥah bil wakalah dapat dilakukan dengan syarat jika barang yang dibeli oleh nasabah sepenuhnya sudah milik lembaga keuangan syariah, kemudian setelah barang tersebut dimiliki bank syariah maka akad murābaḥah dapat dilaksanakan.

\section{Metode Penelitian}

Penelitian ini adalah penelitian lapangan di Bank Rakyat Indonesia Syariah (BRI) Kantor Cabang Sidoarjo. Data dikumpulkan melalui observasi, wawancara dan dokumentasi. Pengamatan dilakukan pada 7 September 2020 s/d 9 Oktober 2020.

\footnotetext{
17 Ibid., 212-213.

18 Saleh Al-Fauzan, Fiqih Praktis Sehari-Hari (Jakarta: Gema Insani, 2005), 428.

${ }^{19}$ Antonio, Bank Syariah: Dari Teori Ke Praktik, 121.

20 Azharsyah Ibrahim and Abdul Jalil Salam, "A Comparative Analysis of DSN-MUI Fatwas Regarding Murabahah Contract and the Real Context Application (A Study at Islamic Banking in Aceh)," Samarah: Jurnal Hukum Keluarga Dan Hukum Islam 5, no. 1 (2021): 375, https://doi.org/10.22373/sjhk.v5i1.8845. 21 Dewan Syariah Nasional MUI, "Fatwa DSN MUI No. 04/DSN-MUI/IV/2000 Tentang Murabahah."
} 
Setelah data terkumpul maka dianalisis secara deskriptif kualitatif. Dalam penelitian kali ini kami menggunakan metode penelitian kualitatif. Secara ringkas penelitian kualitatif dapat dinyatakan sebagai suatu penelitian yang berusaha menemukan dan menggambarkan secara naratif kegiatan yang dilakukan terhadap kehidupan dari narasumber. Dari hasil penuturan narasumber akan kami narasikan dan akan kami analisis dengan teori murābahah bil wakalah.

\section{Hasil dan Pembahasan}

\section{Profil BRI Syariah Sidoarjo}

Sejarah pendirian PT Bank BRIsyariah Tbk tidak lepas dari akuisisi yang dilakukan PT Bank Rakyat Indonesia (Persero) Tbk terhadap Bank Jasa Arta pada 19 Desember 2007. Setelah mendapatkan izin usaha dari Bank Indonesia melalui surat no. 10/67/Kep.GBI/ DPG/2008 pada 16 Oktober 2008 BRIsyariah resmi beroperasi pada 17 November 2008 dengan nama PT Bank BRIsyariah dan seluruh kegiatan usahanya berdasarkan prinsip syariah Islam.

Pada 19 Desember 2008, Unit Usaha Syariah PT Bank Rakyat Indonesia (Persero) Tbk melebur ke dalam PT Bank BRISyariah. Proses spin off tersebut berlaku efektif pada tanggal 1 Januari 2009 dengan penandatanganan yang dilakukan oleh Sofyan Basir selaku Direktur Utama PT Bank Rakyat Indonesia (Persero) Tbk dan Ventje Rahardjo selaku Direktur Utama PT Bank BRISyariah. BRISyariah melihat potensi besar pada segmen perbankan syariah. Dengan niat untuk menghadirkan bisnis keuangan yang berlandaskan pada prinsip-prinsip luhur perbankan syariah, Bank berkomitmen untuk produk serta layanan terbaik yang menenteramkan, BRISyariah terus tumbuh secara positif. BRISyariah fokus membidik berbagai segmen di masyarakat. Basis nasabah yang terbentuk secara luas di seluruh penjuru Indonesia menunjukkan bahwa BRISyariah memiliki kapabilitas tinggi sebagai bank ritel modern terkemuka dengan layanan finansial sesuai kebutuhan nasabah.

BRISyariah terus mengasah diri dalam menghadirkan yang terbaik bagi nasabah dan seluruh pemangku kepentingan. BRISyariah juga senantiasa memastikan terpenuhinya prinsip- prinsip syariah serta Undang-Undang yang berlaku di Indonesia. Dengan demikian, BRISyariah dapat terus melaju menjadi bank syariah terdepan dengan jangkauan termudah untuk kehidupan lebih bermakna. Pada tahun 2018, BRIsyariah mengambil langkah lebih pasti lagi dengan melaksanakan Initial Public Offering pada tanggal 9 Mei 2018 di Bursa Efek Indonesia. IPO ini menjadikan 
BRISyariah sebagai anak usaha BUMN di bidang syariah yang pertama melaksanakan penawaran umum saham perdana. ${ }^{22}$

Adapun visi yang telah di terapkan oleh bank BRI Syariah untuk menjalankan kegiatan perbankan, yaitu:23 Menjadi bank ritel modern terkemuka dengan ragam layanan finansial sesuai kebutuhan nasabah dengan jangkauan termudah untuk kehidupan lebih bermakna. Untuk mencapai visi tersebut, maka bank memiliki misi: Memahami keragaman individu dan mengkomodasi beragam kebutuhan finansial nasabah, menyediakan produk dan layanan yang mengedepankan etika sesuai dengan prinsip-prinsip syariah, menyediakan akses ternyaman melalui berbagai sarana kapanpun dan dimanapun dan memungkinkan setiap individu untuk meningkatkan kualitas hidup dan menghadirkan ketentraman pikiran.

BRI Syariah Cabang Sidoarjo merupakan anak perusahaan dari Bank Rakyat Indonesia yang akan melayani kebutuhan perbankan masyarakat khususnya wilayah Sidoarjo dan sekitarnya dengan menggunakan prinsip-prinsip syariah. Produk produk perbankan di Bank BRI Syariah dibedakan kedalam dua kategori yaitu Pengimpunan Dana (Funding) dan Penyaluran Dana (Financing). Produk dalam kategori funding yaitu tabungan Faedah, Haji, Impian, Simpanan, SimPel, Giro, dan Deposito. Sedangkan, produk financing diantaranya yaitu Griya Faedah, KPR Sejahtera, Oto Faedah Pembiayaan Umrah, KMF Purna, KMF Pra Purna, KMF BRI Syariah, Gadai Faedah, Dan Mikro Faedah.

Sistem operasional bank syariah yang meliputi aspek penghimpunan dan penyaluran dana secara syariah, interaksi antara bank dengan nasabah yang tidak bertentangan dengan syariah. Terkait dengan asas operasional bank syariah, berdasarkan pasal 2 UU Nomor 21 Tahun 2008, disebutkan bahwa perbankan syariah dalam melakukan kegiatan usahanya berasaskan prinsip syariah, demokrasi, dan prinsip kehati-hatian.

\section{Implementasi Akad Murābaḥah Bil Wakalah Dalam Pembiayaan Produk Kredit}

\footnotetext{
${ }^{22}$ https://brisyariah.co.id/ tentang Sejarah BRI Syariah, diakses pada 12 Oktober 2020 pukul 19.10 WIB. ${ }^{23}$ https://brisyariah.co.id/ mengenai visi dan misi BRI Syariah, diakses pada 15 Oktober 2020 pukul 15.15 WIB
} 


\section{Usaha Rakyat (KUR) Di Bank BRI Syariah Kantor Cabang Sidoarjo}

Kredit Usaha Rakyat atau bisa disingkat sebagai (KUR) merupakan salah satu langkah dari pemerintah untuk menciptakan lapangan pekerjaan dan sebagai langkah penanggulangan kemiskinan. Kebijakan ini, memiliki tujuan untuk meningkatkan pemberdayaan pada sektor UMKM. Jika didefinisikan, Kredit Usaha Rakyat adalah kredit atau pembiayaan modal kerja kepada debitur baik individu, badan usaha dan kelompok usaha yang produktif namun belum memiliki agunan tambahan atau agunan tambahan yang belum cukup. Target peruntukan program KUR ini yakni pada sektor usaha pertanian, perikanan perindustrian, jasa keuangan simpan pinjam. Program KUR ini dapat diakses oleh pihak UMKM dan Koperasi di kantor cabang atau kantor cabang pembantu bank pelaksana. ${ }^{24}$

Dalam hal ini, Bank BRI Syariah merupakan salah satu kantor cabang pembantu bank pelaksana yang memiliki tugas untuk melayani nasabah dalam mengajukan pembiayaan KUR. Sama halnya dengan pinjaman syariah yang memakai skema pembiayaan, akad yang digunakan dalam KUR yakni akad Murābaḥah bil Wakalah. BRI Syariah memiliki tiga jenis kredit usaha rakyat yakni KUR miktro IB, KUR mikro Kecil IB, dan KUR TKI. Ketiga jenis kredit usaha rakyat ini memberikan pinjaman serta tenor yang berbeda.

Terdapat hal yang membedakan antara produk KUR yang dimiliki oleh BRI Syariah dan lembaga bank lainnya. Letak perbedaannya yakni terdapat pada proses pengajuan yang cepat dan memiliki bunga yang ringan. Prosentase bunga yang awalnya 7\% pertahun menjadi 6\% efektif pertahun dan mulai berlaku sejak 1 Januari 2020. ${ }^{25}$ Tentunya, kemudahan dan proses yang cepat tersebut bukan tanpa syarat. Selain syarat secara administratif yang harus dipenuhi nasabah, terdapat kriteria tertentu yang harus dipenuhi bagi nasabah yang mengajukan pembiayaan dengan produk KUR. Kriteria tersebut meliputi nasabah perorangan, memiliki usaha produktif, usaha telah berjalan minimal 6 bulan, hasil sistem layanan informasi keuangan (SLIK) harus kolektibilitas lancar, tidak terdapat daftar hitam nasional Bank Indonesia (DHN BI), tidak memiliki kredit maupun pembiayaan dengan tujuan Pembiayaan modal kerja, umur minimal 21 tahun bagi yang belum menikah, umur minimal 18 tahun bagi yang telah menikah, umur maksimal 65 tahun pada saat jatuh tempo pembiayaan, mengisi formulir aplikasi

\footnotetext{
24 “Maksud Dan Tujuan," https://kur.ekon.go.id, n.d., https://kur.ekon.go.id/maksud-dan-tujuan. 25 "Maksud Dan Tujuan."
} 
pengajuan pembiayaan

Selain hal tersebut, hal yang perlu dipahami nasabah yang mengajukan pembiayan KUR di BRI Syariah adalah letak pemahaman bahwa KUR BRI Syariah merupakan hal yang berbeda dengan KUR yang menjadi produk dari Bank Konvensional. Letak perbedaan yang mendasar dari KUR BRI Syariah terletak pada akad yang diterapkan serta besaran bunga yang lebih kecil dan bersifat flat. Dengan penerapan akad murābahah bil wakalah, maka produk KUR di BRI Syariah menerapkan adanya margin bagi hasil (keuntungan pihak bank) sebesar $6 \%$ pertahun atau $0.2 \%$ flat perbulan. Potensi memberikan kemaslahatan bagi pihak nasabah cukup tinggi dengan adanya margin yang bersifat flat. ${ }^{26}$

KUR atau yang dapat diartikan Kredit Usaha Rakyat merupakan salah satu produk pembiayaan mikro yang diperuntukkan bagi wirausaha atau pengusaha dengan syarat usaha yang dilakukan telah brjalan minimal 6 bulan. Plafon yang dapat diajukan nasabah yakni dengan angka maksimal Rp.50.000.000. Produk KUR yang ditawarkan oleh BRI Syariah merupakan salah satu komitmen dari BRI Syariah untuk ikut andil dalam pemajuan UMKM menengah ke bawah. Hal tersebut dikarenakan pada sektor usaha mampu memberikan maslahah kepada masyarakat berupa penyerapan tenaga kerja serta mampu mengangkat perekonomian masyarakat menengah ke bawah untuk keluar dari jurang kemiskinan. ${ }^{27}$

Dalam produk KUR yang ditawarkan BRI Syariah menggunakan akad murābaḥah bil wakalah. Pihak nasabah yang memerlukan bantuan dana tambahan untuk usaha nya dapat mengajukan dengan memilih plafon yang disesuaikan dengan kebutuhan nasabah. Dari pihak BRI Syariah akan meninjau kelayakan diberikannya pinjaman dana serta meminta data diri untuk diakukan BI Checking untuk melacak track record nasabah. Kemudian dari pihak BRI Syariah akan meninjau untuk kedua kalinya namun hal ini dilakukan oleh pihak marketing dan juga mengajak dari pihak pimpinan BRI Syariah. Setelah dilakukan pengecekan kelayakan, dari pihak nasabah dapat datang Ke BRI Syaraiah untuk membawa syarat administratif dan dapat dilakukan pencairan dana. Demi melindungi keamanan dari pihak nasabah, maka dana yang dicairkan akan auto debet dalam tabungan BRI Syariah sang nasabah. Namun, pihak nasabah masih memiliki kewajiban selain mengangsur cicilannya yakni menyetorkan struk belanja

\footnotetext{
${ }^{26}$ Ibid,.

${ }^{27}$ Sauqi, Account Officier Mikro BRI Syariah KC Sidoarjo, wawancara 2 Oktober 2020 
dana yang telah digunakan.

Pada saat nasabah dan bank syariah telah menyetujui adanya pencairan akad, maka nasabah harus memenuhi kewajibannya untuk menyetorkan bukti pembelian kepada bank syariah selambat-lambatnya 14 hari. Dalam kenyataannya, pihak nasabah terkadang lalai akan hal tersebut. Terkadang nasabah menyetorkan struk atau kwitansi belanja yang tidak sesuai dengan akad yang telah disepakati secara bersama sama. Pihak Bank BRI Syariah sudah berusaha untuk memberikan edukasi penyadaran kepada pihak nasabah terkait struk yang harus sesuai dengan akad yang telah disepakati secara bersama sama. Bagaimanapun juga, struk adalah salah satu bentuk kontrol bank terhadap dana yang disalurkan kepada nasabah dan juga merupakan salah satu syarat keabsahan dari akad. Selain struk yang tidak sesuai dengan peruntukannya, mengenai jangka waktu nasabah juga lalai hingga melewati jangka waktu 14 hari setelah akad pencairan dana.

Masalah tersebut sebenarnya bertitik pada ketiadaan barang yang dapat disediakan oleh Bank Syariah dalam memenuhi kebutuhan yang diinginkan oleh pihak nasabah. Hal tersebut dikarenakan salah satu syarat sah dari jual beli yakni adanya ketersediaan barang. Namun, hukum tidaklah suatu hal yang kaku. Demi mencapai kemanfaatan bersama maka beberapa hal yang dapat dijadikan pondasi berfikir yakni melihat kondisi Bank Syariah yang baru berkembang di Indonesia serta minat masyarakat terhadap Bank Syariah yang cukup tinggi maka mengharuskan Bank Syariah memberikan pelayanan terbaik bagi nasabah dengan tidak melupakan aspek tujuan dari syariat. Kondisi bank yang belum mampu menyediakan barang dapat diatasi dengan mewakilkan kepada nasabah kebutuhan yang diinginkan dari pihak nasabah. Prinsip hukum yang dapat dipegang yakni suatu perkara pada hakikatnya boleh asalkan tidak ada hukum yang melarangnya.

Bank pun tidak lepas tangan terkait masalah tersebut dengan cara mengontrol pembelian dari dana yang telah disalurkan ke nasabah. Kontrol tersebut dilakukan melalui kwitansi belanja yang harus disetorkan oleh pihak nasabah setelah uang dihabiskan untuk belanja kebutuhan sesuai dengan akad yang telah disepakati. Namun, dari kelonggaran tersebut bukanlah hal yang harus diremehkan. Selain dengan cara edukasi kepada pihak nasabah agar menyetorkan struk belanja, bank harus benar benar tegas agar struk yang disetorkan sesuai dengan spesifikasi baranng yang telah disepakati didalam akad. Ketegasan tersebut bukan bermaksud membuat nasabah tidak 
nyaman, akan tetapi sebagai bentuk cara agar akad yang telah disepakati benar benar dilakukan oleh kedua belah pihak baik dari pihak bank syariah maupun dari nasabah.

\section{Analisis Murabahah bil Wakalah terhadap Pembiaayaan KUR di BRIS Sidoarjo}

Usaha Mikro Kecil Menengah atau yang sering disebut sebagai UMKM merupakan salah satu motor penggerak perekonomian di lapisan paling organik. Tidak dapat dipungkiri keberadaan UMKM sangatlah membantu masyarakat dalam memutus rantai kemiskinan dan pengangguran. Sementara Bank Syariah merupakan lembaga yang bertugas untuk menghimpun dan menyalurkan dana kepada masyarakat. Terdapat suatu relasi fungsional antara UMKM dan Bank Syariah. Relasi tersebut dapat terbaca dari pola UMKM yang sebenarnya membutuhkan gelontoran dana. Bank Syariah memiliki tugas untuk mengedarkan peredaran uang yang mampu menaikkan kondisi UMKM agar lebih maju dari kondisi sebelumnya. Usaha tersebut dapat diwujudkan dengan program pinjaman dan salah satu produk tersebut yakni Kredit Usaha Rakyat dengan menerapkan akad Murābaḥah bil Wakalah. Namun, KUR tersebut bukan tanpa kendala. Masyarakat yang kurang memahami bagaimana mekanisme KUR dan kewajiban yang wajib dijalankan oleh nasabah membuat suatu hambatan terakit keabsahan dari suatu akad. Maka dari permasalahan tersebut, jurnal ini berfungsi untuk memberi penyadaran kepada pihak Bank dan masyarakat agar produk KUR benar benar mampu mengatasi problem yang dialami oleh UMKM.

Pada praktik perbankan syariah Bank BRI Syariah akad murābaḥah adalah pembiayaan berdasarkan akad jual beli antara bank selaku penjual dan nasabah selaku pembeli. Bank membeli barang yang dibutuhkan dan menjualnya kepada nasabah sebesar harga pokok ditambah dengan keuntungan margin yang disepakati.

Dalam implementasinya bank mewakilkan secara penuh kepada nasabah dan hanya menerima bukti kwitansi yang menjadi terpenuhinya akad murābaḥah bil wakalah. Akan tetapi, dengan pemahaman yang minim masih ditemukan masalah dalam bukti kwitansi pembelian barang yang telah disepakati tatkala tidak sesuai dengan apa yang dimohonkan nasabah pada saat pengajuan permphonan pembiayaan KUR. Maka dari itu, kami rasa hal tersebut dapat diminimalisir dengan cara edukasi kepada pihak nasabah agar menyetorkan struk belanja serta kontrol yang lebih tegas dari bank BRI Syariah KC Sidoarjo agar struk yang disetorkan sesuai dengan spesifikasi baranng yang telah disepakati di dalam akad. Ketegasan tersebut bukan bermaksud membuat nasabah tidak nyaman, akan tetapi sebagai bentuk cara agar akad yang telah disepakati 
benar benar dilakukan oleh kedua belah pihak baik dari pihak bank syariah maupun dari nasabah.

Kita dapat memahai murābaḥah bil wakalah dengan sederhana yaitu jual beli dengan diawali bank syariah mewakilkan membeli produk yang telah diinginkan nasabah serta dilakukan oleh nasabah, kemudian produk yang telah didapatkan diberikan kepada bank syariah. setelah barang tersebut dimiliki pihak bank syariah dan mengenai harga dari barang yang diinginkan nasabah harus jelas. Maka pihak bank syariah dapat menentukan margin keuntungan yang didapat serta menyepakati jangka waktu untuk pengembalian dana yang diterima nasabah beserta besar plafond yang dipilih nasabah. ${ }^{28}$

Hal ini dipertegas Fatwa DSN MUI pada pasal 2 ayat 2 dan 3 yang berbunyi: "Jika bank menerima permohonan tersebut, ia harus membeli terlebih dahulu aset yang dipesannya secara sah dengan pedagang. Bank kemudian menawarkan aset tersebut kepada nasabah dan nasabah harus menerimanya (membelinya) sesuai dengan perjanjian yang disepakati, karena secara hukum perjanjian tersebut mengikat: kemudian kedua belah pohak harus membuat kontrak jual beli." 29

Sebagai bagian dari jual-beli, maka rukun dan syarat akad murābaḥah pada dasarnya sama dengan rukun dan syarat jual beli secara umum. Mazhab Hanafi berpendapat bahwa rukun jual beli adalah ijab dan qobul yang menunjukkan adanya kegiatan saling memberi yang menempati kedudukan ijab dan qobul tersebut. Sedangkan menurut jumhur ulama, rukun dalam jual beli terdapat empat rukun yaitu penjual,pembeli, barang atau objek, dan ijab kabul. Jual beli murābaḥah menjadi sah jika telah memenuhi mengetahui harga pertama, mengetahui besarnya laba atau margin keuntungan yang diperoleh penjual, modal berupa komoditas yang memiliki kesamaan dan sejenis, harta riba hendaknya tidak menisbatkan riba tersebut dalam harga asli, dan transaksi pertama harus sah menurut syariat Islam. Rukun dalam jual-beli (akad) murābaḥah bil wakalah dalam transaksi di perbankan syariah adalah sebagai berikut:

Penjual merupakan orang yang telah cakap menurut hukum dan tidak dalam keadaan terpaksa. Penjual dalam akad murābaḥah ditransaksi jual-beli adalah seseorang yang memiliki barang dagangan atau menawarkan barang kepada pihak kedua atau pembeli. Sedangkan transaksi melalui perbankan syariah maka pihak

\footnotetext{
28 Qomarul Huda, Fiqh Muamalah (Yogyakarta: Teras, 2011), 91.

29 Dewan Syariah Nasional MUI, "Fatwa DSN MUI No. 04/DSN-MUI/IV/2000 Tentang Murabahah.”
} 
penjual adalah bank. Dalam perbankan syariah, pihak bank yang membiayai pembelian barang yang telah diajukan oleh pemohon pembiayaan atau nasabah dengan sistem pembayaran yang ditangguhkan. Akan tetapi, di dalam penerapannya di Bank BRI Syariah KC Sidoarjo maupun perbankan syariah di Indonesia menerapkan akad murābaḥah bil wakalah. Jadi bank mempercayakan penuh pembiayaan tersebut kepada nasabah, di mana nasabah sendiri membeli barang yang diinginkan akan tetapi mengatasnamakan pembelian tersebut oleh bank syariah. ${ }^{30}$

Pembeli adalah orang yang meminta permintaan produk kepada penjual atau terhadap barang yang ditawarkan oleh penjual. Pembeli ialah seseorang yang ingin memperoleh barang yang dibutuhkan dengan membayar jumlah uang yang telah disepakati kepada penjual. Didalam transaksi perbankan syariah, pembeli adalah nasabah atau dengan kata lain pembeli adalah nasabah yang mengajukan permohonan pembiayaan Murābahah bil Wakalah. Bank BRI Syariah memiliki persyaratan mengenai pembeli yaitu nasabah yang telah memiliki tabungan di Bank BRI Syariah atau calon nasabah Bank BRI Syariah (pembeli) merupakan pihak yang cakap menurut hukum dan tidak terpaksa dalam mengajukan permohonan pembiayaan Murābahah bil Wakalah dengan produk pembiayaan KUR.

Objek jual beli adalah benda atau objek yang diperjual-belikan dan memiliki sertifikasi halal. Objek yang diperjualbelikan harus bermanfaat, sesuai dengan spesifikasi yang dinginkan pembeli, penjual dapat menyerahlan objek, tidak termasuk objek atau barang yang diharamkan dan dilarang. Lain halnya didalam transaksi perbankan syariah, objek jual beli dalam permohonan pembiayaan murābaḥah yang sebagian besar nasabah adalah barang yang bersifat konsumtif untuk memenuhi kebutuhan produktif, seperti rumah, mobil, tanah, motor, modal usaha, dan sebagainya. Bank BRI Syariah memiliki produk pembiayaan yang menggunakan akad murābaḥah dengan objeknya adalah rumah, perabot rumah tangga, mobil atau kendaraan bermotor, dan barang untuk usaha.

Harga adalah alat ukur untuk menentukan nilai dari suatu barang. Harga juga dapat diartikan dengan jumlah uang yang harus dibayarkan untuk barang dagangan. Harga dalam transaksi pembiayaan akad murābaḥah digunakan sebagai patokan berapa margin keuntungan yang disepakati oleh kedua belah pihak. Sedangkan harga dalam

\footnotetext{
30 Muhammad, Model-Model Akad Pembiayaan Di Bank Syariah (Panduan Teknis Pembuatan Akad/Perjanjian Pembiayaan Pada Bank Syariah) (Yogyakarta: UII Press, 2009), 58.
} 
permohonan pembiayaan murābaḥah di perbankan syariah dianalogikan sebagai pricing dan plafond pembiayaan.

Ijab merupakan perkataan yang diucapkan oleh penjual atau seseorang yang mewakilkannya untuk mengutarakan maksud dari tujuan akad yang akan terjalin. Sedangkan Qobul adalah perkataan yang diucapkan oleh pembeli atau ekspresi yang mewakilkan maksud dari pembeli melakukan akad. Di dalam transaksi perbankan syariah ijab dan qabul dalam pembiayaan murābaḥah tertulis di surat perjanjian pembiayaaan murābaḥah. Dalam akad biasanya berisi mengenai spesifikasi barang yang diinginkan nasabah atau perincian tentang permohonan yang diajukan oleh nasabah, kesediaan pihak bank syariah dalam menyediakan barang permintaan nasabah, juga pihak bank syariah harus memberitahukan harga pokok pembelian serta margin keuntungan yang ditawarkan kepada nasabah (terjadi penawaran), kemudian penentuan berapa lama angsuran yang nasabah mampu, maka kesepakatan tersebut dapat dikatakan menggunakan akad murābaḥah. Sighat harus jelas meliputi harga dan barang yang disepakati harus seimbang serta tidak dibatasi oleh waktu dan tidak bersifat mengguntungkan pada transaksi yang akan datang. Akan tetapi, diantara ijab dan qabul harus selaras. Selain itu harus ada muwakil atau pemberi kuasa dalam hal ini pihak yang memberikan kuasa (bank syariah) untuk mewakilkan membeli barang sesuai keinginan nasabah kepada pihak lain (nasabah)

Sedangkan syarat jual-beli dengan menggunakan akad Murābahah bil Wakalah yaitu penjual harus memberitahu harga pokok kepada calon pembeli, perjanjian jual beli Murābahah bil Wakalah harus sah sesuai dengan rukun yang telah diterapkan dan terbebas dari unsur keribawian, penjual harus menjelaskan kepada pembeli bila pada saat barang diterima dan terjadi cacat atas barang yang dipesan, dan penjual harus menyampaikan semua hal yang berkaitan dengan pembelian, misalya jika pembelian dilakukan secara utang. ${ }^{31}$

Secara prinsip jika syarat dalam urutan pertama, ketiga dan keempat tidak dipenuhi, maka pembeli memiliki hak pilih yaitu dapat melanjutkan pembelian seperti apa adanya, kembali kepada penjual dan menyatakan ketidaksesuaian dengan barang yang dijual, dan membatalkan kontrak. Skema proses jual-beli dalam prespektif fiqih tentang transaksi Murābaḥah secara sederhana, seperti berikut: ${ }^{32}$

\footnotetext{
31 Mujahidin, Hukum Perbankan Syariah, 56.

32 Ibid., 56.
} 
Tabel 2. Skema Jual Beli Murābahah

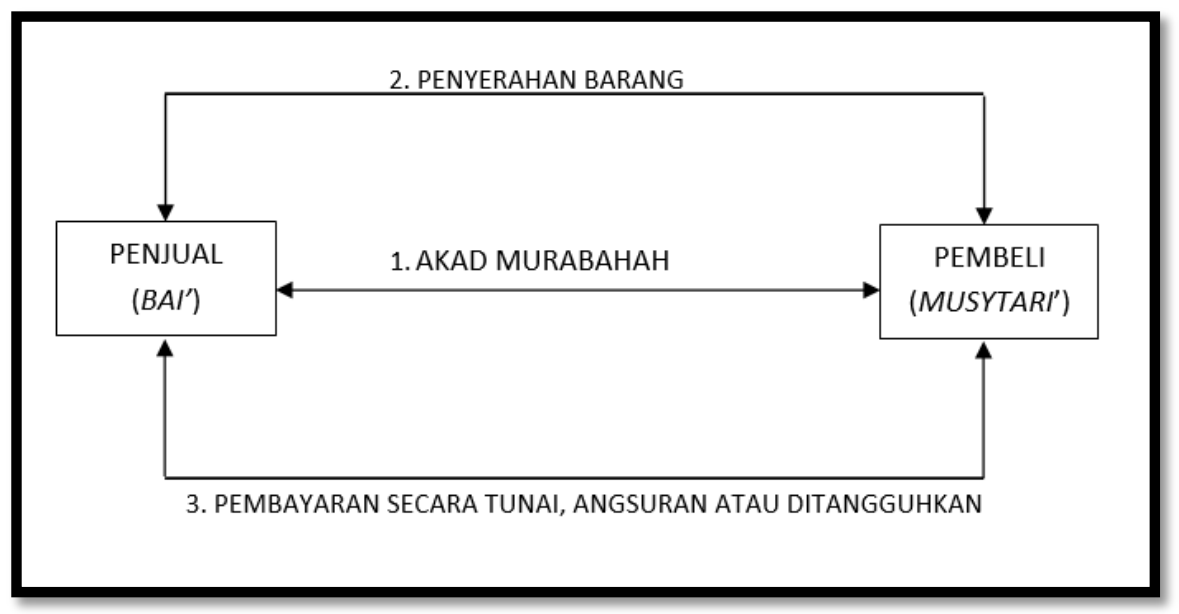

Dari skema d iatas dapat dipahami bagaimana transaksi jual-beli menggunakan akad murābaḥah dalam prespektif fiqih yaitu penjual (bai') bersama pembeli (musytari') melakukan transaksi jual-beli menggunakan akad murābaḥah, kemudian pembeli menyerahkan barang kepada penjual dengan memberitahu harga pokok barang yang dipesan beserta margin keuntungan yang diperoleh penjual, dan pembeli melakukan pembayaran baik secara tunai, angsuran atau ditangguhkan kepada penjual sesuai dengan kesepakatan anatara kedua belah pihak.

Di perbankan syariah menggunakan konsep pembiayaan yang dapat dibedakan menjadi dua jenis yaitu pembiayaan murābaḥah tanpa pesanan dan pembiayaan murābaḥah berdasarkan pesanan. ${ }^{33}$ Pembiayaan murābaḥah tanpa pesanan pembiayaan murābaḥah yang dilaksanakan tanpa melihat apakah ada pesanan atau permohonan pembiayaan dari nasabah, sehingga penyediaan barang dilakukan oleh bank syariah sendiri dan belum terikat dengan akad jual-beli murābaḥah. Dapat kita pahami, bahwa pembiayaan murābaḥah tanpa pesanan yaitu apabila bank syariah telah menyediakan barang akan tetapi tidak ada nasabah yang mengajukan permohonan pembiayaan murābaḥah. Dengan kata lain, bank syariah menyediakan barang yang akan diperjual-belikan dengan nasabah tanpa memperhatikan nasabah yang mengajukan permohonan pembiayaan murābaḥah. Pengadaan barang yang dilakukan oleh bank syariah dapat dilakukan dengan memperhatikan beberapa cara, diantaranya ialah membeli barang kepada produsen (akad murābaḥah), memesan kepada produsen dengan pembayaran secara keseluruhan setelah terjadinya akad (akad salam), memesan kepada produsen dengan pembayaran dilakukan sebagian di awal, selama masa produksi, setelah barang yang dipesan telah selesai (akad istishna'), merupakan

33 Wiroso, Jual Beli Murabahah, 37. 
barang-barang dari persediaan musyarakah dan mudharabah.

Pembiayaan murābaḥah berdasarkan pesanan terjadi apabila ada nasabah yang telah mengajukan permohonan pembiayaan murābaḥah. Pembiayaan murābaḥah berdasarkan pesanan adalah jual beli yang dilakukan bank syariah setelah adanya permohonan yang diajukan nasabah. Dengan hal ini, bank syariah selaku penjual menyediakan barang atau asset setelah adanya pesanan yang diajukan oleh nasabah. Bank BRI Syariah KC Sidoarjo menggunakan jenis pembiayaan murābaḥah berdasarkan pesanan karena pada implementasinya menerapkan akad murābahah bil Wakalah sesuai dengan permohonan dari nasabah. Bank selaku penjual memercayakan kepada nasabah sepenuhnya untuk efisiensi waktu dan tempat penyimpanan barang.

Tabel 3. Skema Pembiayaan murābaḥah bil Wakalah

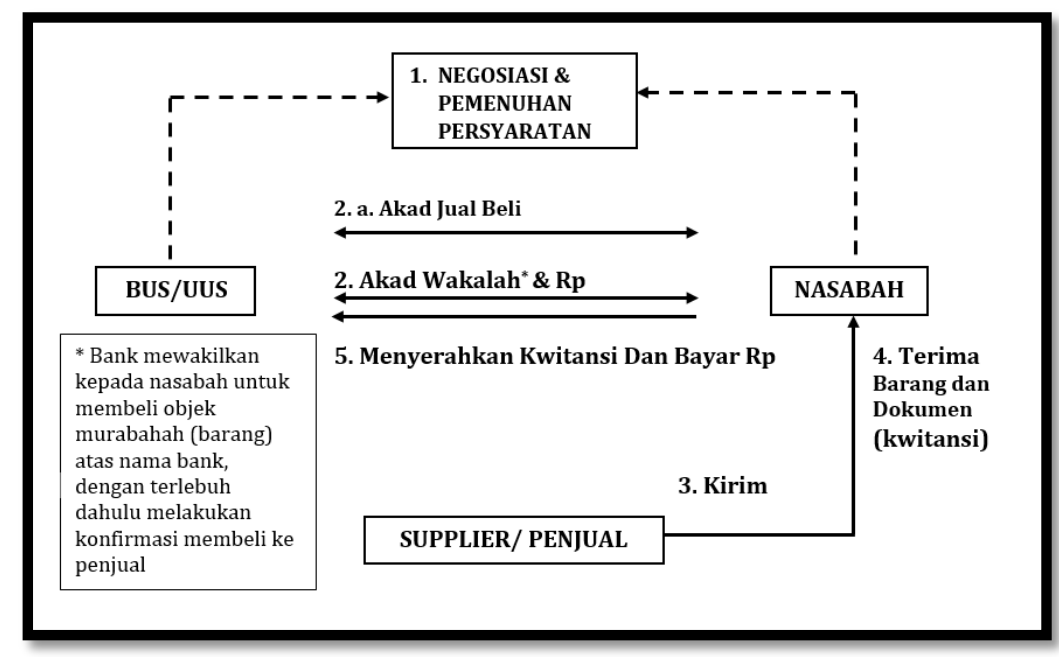

Dari skema pembiayaan murābaḥah bil Wakalah dapat dipahami bahwasannya nasabah dengan bank umum syariah (BUS) melakukan negosiasi dan pemenuhan persyaratan meliputi berapa besar dana yang diterima nasabah, jaminan yang dijaminkan nasabah, kemudian untuk pembiayaan KUR harus memenuhi persyaratan telah memiliki usaha sekurang-kurangnya satu tahun usaha berjalan. Setelah mendapat kesepakatan bersama, terjadi akad murābaḥah bil Wakalah dan pencairan dana sehingga nasabah membeli kebutuhan sesuai yang dimohonkan nasabah kepada supplier atau penjual. Kemudian, barang dikirim dan nasabah menerima barang dan dokumentasi berupa kwitansi. Setelah barang di dapatkan nasabah dan mendapatkan kwitansi, nasabah menyerahkan kwitansi dan membayar angsuran sesuai dengan akad perjanjian.

Dengan adanya pembiayan murābaḥah di Perbankan Syariah juga memiliki tujuan atau manfaat bagi bank syariah sendiri dan bagi nasabah. Adapun tujuan atau 
manfaat bagi bank yaitu sebagai salah salu bentuk penyaluran dana dan memperoleh pendapatan dalam bentuk margin. Sedangkan bagi nasabah merupakan salah satu alternatif untuk memperoleh barang tertentu melalui pembiayaan dari bank syariah dan dapat mengangsur pembayaran dengan jumlah angsuran yang tidak akan berubah selama masa perjanjian. Perlu dipahami kembali bahwa pasti ada resikonya, dimana resiko dari pembiayaan Murābaḥah ada dua yakni Risiko Pembiayaan (financial risk) yang disebabkan oleh nasabah wanprestasi dan Risiko Pasar yang disebabkan oleh pergerakan nilai tukar jika pembiayaan atas dasar Akad Murābaḥah diberikan dalam valuta asing. ${ }^{34}$

Perbankan syariah sudah banyak yang berkembang di Indonesia dan mengadopsi berbagai kontrak jual-beli sesuai dengan akad akad dalam muamalah untuk membantu pendanaan konsumennya. Dalam pengaplikasiaan akad murābaḥah di perbankan syariah, bank sebagai penjual dan nasabah sebagai pembeli begitupun sebaliknya. Ketika bank menjadi penjual maka, bank harus menyediakan barang yang diminta oleh nasbah dengan membeli barang dari suplier lalu menjual barang yang diminta kepada nasabah yang mengajukan pembiayaan murābaḥah dengan harga yang telah ditambah margin keuntungan yang telah disepakati antara bank syariah dan nasabah. Pembayaran dapat dilakukan sesuai perjanjian antar keduanya, dapat diangsur selama jangka waktu yang telah ditetapkan maupun dibayar secara sekaligus pada saat jatuh tempo. ${ }^{35}$ Prinsip yang digunakan diperbankan syariah berdasarkan dua elemen pokok, yaitu: harga beli serta biaya yang terkait, dan kesepakatan atas mark up (laba). Bank syariah mengadopsi akad murābaḥah sebagai salah satu akad untuk memberikan pembiayaan jangka pendek kepada para nasabah guna pembelian barang meskipun nasabah tidak dapat memenuhi kewajiban sesuai dengan perjanjian yang telah disepakati.

Dasar ciri-ciri dari perjanjian murābaḥah sebagai jual-beli dengan pembayaran ditangguhkan yaitu pembeli atau nasabah harus memiliki pengetahuan tentang biayabiaya terkait mengenai harga pokok barang serta batas laba yang diperoleh oleh penjual, harus ditetapkan dalam bentuk presentase dari total keseluruhan biaya-biaya yang timbul akibat pembiayaan murābaḥah; apa yang diperjual-belikan adalah barang atau komoditas yang dapat dibeli dengan uang; apa yang diperjual-belikan, penjual

\footnotetext{
${ }^{34}$ Muhammad, Manajemen Dana Bank Syariah (Jakarta: Rajawali Press, 2015), 47.

35 Roifatus Syauqoti and Mohammad Ghozal, "Aplikasi Akad Murabahah Pada Lembaga Keuangan Syariah," Jurnal Musharif Al-Syariah: Jurnal Ekonomi Dan Perbankan Syariah 3, no. 1 (2018): 7-8.
} 
Rahmi Eka Ratnani, dkk : Pembiayaan Kredit Usaha ...

telah memiliki barang tersebut dan mampu menyerahkan barang tersebut kepada pembeli; pembayaran ditangguhkan atau dapat diangsur sesuai dengan kesepakatan. ${ }^{36}$

\section{E. Kesimpulan}

Berdasarkan hal tersebut maka pembiayaan KUR di Bank BRI Syariah telah sesuai dengan konsep murābaḥah bil Wakalah karena sudah memenuhi unsur dan subjeknya. Problematika yang terjadi dalam proses pembiayaan murābahah bil Wakalah di Bank BRI merupakan bagian dari resiko murābaḥah bil Wakalah. Dibutuhkan kerjasaman dan kejujuran serta kapatuhan antara pihak bank dan nasabah agar pembiayaan murābaḥah bil Wakalah bisa diterapkan dengan baik.

\section{Daftar Pustaka}

Afrida, Yenti. "Analisis Pembiayaan Murabahah Di Perbankan Syariah." Jebi (Jurnal Ekonomi Dan $\begin{array}{lllll}\text { Bisnis Islam) } \quad 1, \quad \text { no. } & 2 & \text { (2016): }\end{array}$ http://journal.febi.uinib.ac.id/index.php/jebi/article/view/32.

Al-Fauzan, Saleh. Fiqih Praktis Sehari-Hari. Jakarta: Gema Insani, 2005.

Antonio, Muhammad Syafii. Bank Syariah: Dari Teori Ke Praktik. Jakarta: Gemma Insani, 2001.

Dewan Syariah Nasional MUI. "Fatwa DSN MUI No. 04/DSN-MUI/IV/2000 Tentang Murabahah." Jakarta, 2000.

Fajri AF, Muh Shadiqul. "Penerapan Shariah Compliance Dalam Alur Pembiayaan Murabahah Pada Bank Muamalat Indonesia Cabang Makassar." Jurnal Iqtisaduna 6, no. 1 (2020): 25-44. https://doi.org/10.24252/iqtisaduna.v6i1.14061.

Haida, Nur, Gama Pratama, Toto Sukarnoto, and Widiawati. "Pengaruh Pemahaman Masyarakat Tentang Riba Terhadap Minat Bertransaksi Di Bank Syariah." Ecobankers: Journal of Economy Banking 2, no. 2 (2021): 131-39.

Huda, Qomarul. Fiqh Muamalah. Yogyakarta: Teras, 2011.

Ibrahim, Azharsyah, and Abdul Jalil Salam. "A Comparative Analysis of DSN-MUI Fatwas Regarding Murabahah Contract and the Real Context Application (A Study at Islamic Banking in Aceh)." Samarah: Jurnal Hukum Keluarga Dan Hukum Islam 5, no. 1 (2021): 372-401. https://doi.org/10.22373/sjhk.v5i1.8845.

“Konsep Murabahah Dalam Wacana Fikih." In Ensikolpedi Fikih Online, 2010. http://fikihonline.blogspot.com/search?q=murabahah.

https://kur.ekon.go.id. "Maksud Dan Tujuan," n.d. https://kur.ekon.go.id/maksud-dan-tujuan.

Muhammad. Manajemen Dana Bank Syariah. Jakarta: Rajawali Press, 2015.

- - - Model-Model Akad Pembiayaan Di Bank Syariah (Panduan Teknis Pembuatan Akad/Perjanjian Pembiayaan Pada Bank Syariah). Yogyakarta: UII Press, 2009.

Mujahidin, Akhmad. Hukum Perbankan Syariah. Depok: PT Raja Grafindo Persada, 2017.

Mutmainnah, Nurul Afiqah, and Hadi Daeng Mapuna. "Peranan Restrukturisasi Dalam Akad Murābahah (Studi Kasus Putusan Nomor: 0293/Pdt.G/2017/ PA . Gtlo).” Qaḍāunā 1, no. 2 (2020): 87-101.

Riawan, Riawan, and Wawan Kusnawan. "Pengaruh Modal Sendiri Dan Kredit Usaha Rakyat (KUR) Terhadap Pendapatan Usaha (Studi Pada UMKM Di Desa Platihan Kidul Kec. Siman)." Jurnal Akuntansi Dan Pajak 19, no. 1 (2018): 31-37. https://doi.org/10.29040/jap.v19i1.158.

Otoritas Jasa Keuangan. "Statistik Perbankan Syariah - Agustus 2020," 2020. https://www.ojk.go.id/id/kanal/syariah/data-dan-statistik/statistik-perbankan-

36 Mujahidin, Hukum Perbankan Syariah, 57. 
Rahmi Eka Ratnani, dkk : Pembiayaan Kredit Usaha ...

syariah/Pages/Statistik-Perbankan-Syariah---Agustus-2020.aspx.

Syarif, Fitrianur. "Perkembangan Hukum Ekonomi Syariah Di Indonesia." Pleno Jure 9, no. 2 (2019): 1-16. https://doi.org/10.37541/plenojure.v8i2.38.

Syauqoti, Roifatus, and Mohammad Ghozal. "Aplikasi Akad Murabahah Pada Lembaga Keuangan Syariah.” Jurnal Musharif Al-Syariah: Jurnal Ekonomi Dan Perbankan Syariah 3, no. 1 (2018).

Vogel, Frank E., and Samuel L. Hayes. Islamic Law and Finance (Religion, Risk, and Return). Netherlands: Kluwer Law International, 1998.

Wiroso. Jual Beli Murabahah. Yogyakarta: UII Press, 2005. 